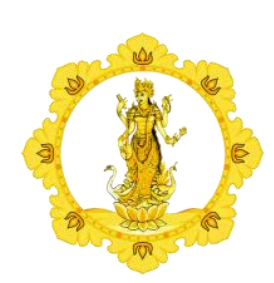

KALANGWAN

JURNAL PENDIDIKAN AGAMA, BAHASA DAN SASTRA

Vol. 11 No. 1 Maret 2021

\begin{tabular}{|c|c|l|} 
p-ISSN : 1979-634X & e-ISSN : 2686-0252 & http://ejournal.indn.ac.id/index.php/Kalangwan
\end{tabular}

\title{
PENGEMBANGAN MATERI MUATAN LOKAL DI SEKOLAH MENENGAH ATAS 1 BATURITI
}

\author{
Oleh : \\ I Made Dharmawan, I Nyoman Mandiasa \\ Universitas Hindu Negeri I Gusti Bagus Sugriwa Denpasar \\ E-mail: putueddy84@gmail.com, rivaprathiwiriva@gmail.com, rumintenkadek@gmail.com
}

Diterima 16 Januari 2021, direvisi 19 Januari 2021, diterbitkan 31 Maret 2021

\begin{abstract}
Education plays an important role in developing human resources and developing a whole person. Learning programs and educational programs are contained in an educational material program guide called the curriculum. The current curriculum in Indonesia is called the 2013 Curriculum. The 2013 curriculum applies comprehensively and integrally in education levels both at the primary level and education at the general secondary level (SMA) or vocational secondary education (SMK). The curriculum is outlined in more detail and is more immersive in the syllabus. The syllabus is arranged by the center, according to the students' conditions and abilities. The syllabus is compiled and detailed and developed in the form of an RPP (Learning Implementation Plan). In relation to the authority that schools have over the development of local content, SMA $N 1$ Baturiti develops local content skills for making burials for female students and weaving skills for male students. The theory used in this research is the theory of hegemony, social capital theory and constructivist theory. This type of research in order to obtain all the necessary data used qualitative research with qualitative descriptive methods, while the data collection technique was through document study interviews obtained from Hindu religious teachers and students of SMA N 1 Baturiti. From the results of the analysis, it is found that the efforts to develop local content at SMA N 1 Baturiti are the development and deepening of the syllabus of Hindu Religion subjects, especially in the field of Hindu religious ceremonies. related to Hinduism for male students.
\end{abstract}

\section{Keywords: Development Of Local Content Material}




\section{PENDAHULUAN}

Pendidikan memegang peranan penting dalam mewujudkan cita-cita bangsa yang ingin memperbaiki nasib dan masa depan bangsanya. Pendidikan diharapkan mampu melahirkan generasi yang mandiri, kritis, rasional, cerdas, kreatif, serta memiliki kesabaran dan mampu untuk bersaing, siap dalam menghadapi berbagai macam perubahan sekaligus tantangan. Pendidikan dilaksanakan sebagai usaha manusia dalam mengembangkan peserta didik menjadi insan yang memiliki: kekuatan spiritual keagamaan, pengendalian diri, kepribadian, kecerdasan, ahlak mulya, serta ketrampilan yang diperlukan dirinya demi masyarakat bangsa dan negara (Undang-Undang Nomor 20 tahun 2003 tentang Sisdiknas). Pendidikan menengah adalah basis dari pembentukan perilaku manusia (peserta didik), oleh karena itu pendidikan menengah dalam pengelolaannya merupakan satu sistem yang utuh (Tillar, 1992: 92).

Proses penyelenggaraan pendidikan dalam pembentukan perilaku peserta didik memiliki hubungan kausalitas, masingmasing institusi sama-sama berperan dan memiliki hubungan timbal balik diantara lembaga penyelenggara pendidikan. Berdasarkan Undang-Undang Nomor 20 Tahun 2003, tentang Sisdiknas yang termasuk rumpun/jenjang pendidikan menengah adalah terdiri dari pendidikan menengah umum dan pendidikan menengah kejuruan. Pendidikan menengah berbentuk Sekolah Menengah Atas (SMA) dan Sekolah Menengah Kejuruan (SMK). Dewasa ini telah ditempuh berbagai upaya untuk meningkatkan mutu pendidikan di Indonesia untuk mewujudkan anak didik menjadi insan seperti yang dicita-citakan dalam tujuan pendidikan Nasional di atas. Salah satu upaya yang ditempuh yakni: dengan mengembangkan kurikulum yang mengadopsi potensi daerah yang disebut muatan lokal. Lebih lanjut disampaikan bahwa muatan lokal adalah kegiatan kurikuler yang dilaksanakan untuk mengembangkan kompetensi yang disesuaikan dengan ciri khas dan potensi yang dimiliki oleh masing-masing daerah (Sutriyanti, 2020: 18).

Kemampuan tenaga pendidik dalam kegiatan pembelajaran muatan lokal akan memberikan peluang untuk mengembangkan kearifan lokal yang ada di masing-masing daerah. Perkembangan ilmu pengetahuan dan teknologi tampaknya mendorong tenaga pendidik untuk dapat memahami lebih mendalam ilmu pengetahuan dan teknologi serta kearifan lokal melalui pembelajaran yang direncanakan berdasarkan Kurikulum Tingkat Satuan Pendidikan. Kehadiran muatan lokal dalam pendidikan formal tidak bisa dilepaskan dari hubungan antara pendidikan dan masyarakat. Dalam kaitan ini Dantes menguraikan secara jelas bahwa hubungan antara sekolah dengan masyarakat menjadi sangat penting, sebab apa yang diharapkan oleh masyarakat akan menentukan sistem pendidikan. Pendiidkan formal berfungsi untuk mengajarkan pengetahuan umum dan pengetahuan yang bersifat khusus dalam rangka menyiapkan anak untuk pekerjaan-pekerjaan tertentu (Dantes, 1966: 37).

Konsep dasar pembelajaran muatan lokal, jika dikaitkan dengan persoalan mutu lulusan pendidikan seperti yang telah diuraikan di atas, secara konsepsional sangat ideal. Pembelajaran yang menitik beratkan pada konteks yang ada, maka terakomodasilah aktifitas kehidupan nyata dalam proses pembelajaran. Peserta didik yang tamat tidak merasa asing ketika berhadapan dengan kondisi nyata dalam aktifitas kehidupan beragama dan adat dalam masyarakat. Pola pembelajaran muatan lokal memberikan peluang yang lebih besar kepada guru untuk membawa aktifitas kehidupan beragama di masyarakat ke dalam situasi proses belajar mengajar. Dengan demikian proses pembelajaran materi muatan lokal akan dapat berdaya guna demi kepentingan peserta didik dan masyarakat.

\section{PEMBAHASAN}

2.1 Pengembangan Materi Muatan Lokal di Sekolah Menengah Atas 1 Baturiti 2.1.1 Pengembangan dalam Kurikulum 
Menurut Muhammad Joko Susilo (2015: 117) menyebutkan, pengembang silabus berisi, yaitu 1) tata kerja, kewenangan dan pesan pusat, provinsi, kabupaten /kota, dan sekolah. Sesuai dengan pelaksanaan otonomi daerah dan kebijakan Depdiknas, struktur organisasi tata laksana, pengembangan silabus hendaknya menggambarkan bahwa pusat berperan menentukan standar kompetensi, kompetensi dasar, standar materi. Sedangkan daerah atau sekolah berperan menjabarkan kemampuan dasar, menjadi materi pembelajaran, pengalaman belajar siswa, alokasi waktu, dan sumber acuan, 2) pedoman tata cara, dan prosedur penjabaran kemampuan dasar menjadi materi pembelajaran, pengalaman belajar siswa, dan alokasi waktu. Pengembangan silabus diwujudkan dalam dua pedoman, yaitu: 1) pedoman umun yang berisikan petunjuk umum tata cara pengembangan silabus, dan 2) pedoman khusus yang berisikan petunjuk khusus tata cara dan prosedur pengembangan silabus mata pelajaran.

Selanjutnya dalam Kurikulum menyebutkan Pengembangan Rencana Pelaksanaan Pembelajaran (RPP) hendaknya memperhatikan karakteristik peserta didik terhadap materi standar yang dijadikan bahan kajian. Dalam pengembangan Rencana Pelaksanaan Pembelajaran (RPP) guru disamping berperan sebagai transformator, tetapi berperan juga sebagai motivator yang dapat membangkitkan gairah dan nafsu belajar, serta mendorong peserta didik untuk belajar dengan menggunakan berbagai variasi media dan sumber belajar dalam menunjang pembentukan standar kompetensi dan kompetensi dasar. Menurut Mulyasa (Mulyasa, 2014: 2009) menyebutkan ada beberapa prinsip dalam pengembangan Rencana Pelaksanaan Pembelajaran (RPP), yaitu: 1) kompetensi yang dirumuskan dalam Rencana Pelaksanaan Pembelajaran harus jelas, 2) Rencana Pelaksanaan Pembelajaran (RPP) harus sederhana, fleksibel, serta dapat dilaksanakan dalam kegiatan pembelajaran, dan pembentukan kompetensi peserta didik, 3) kegiatan yang disusun dan dikembangkan dalam Rencana Pelaksanaan pembelajaran (RPP) harus menunjang, dan sesuai dengan kompetensi dasar yang akan diwujudkan, 4) Rencana Pelaksanaan Pembelajaran (RPP) yang dikembangkan harus utuh dan menyeluruh, serta jelas pencapaiannya dan 5) ada koordinasi antar komponen pelaksanaan program di sekolah, terutama apabila pembelajaran dilaksanakan antar tim atau dilaksanakan di luar kelas, agar tidak menganggu jam-jam pelajaran yang lain. Lebih lanjut disampaikan bahwa dengan adanya perubahan kurikulum tahun 2013 ini tentunya sangat berdampak terhadap situasi pembelajaran di kelas dan mutu pendidikan secara umum (Sutriyanti, 2017: 1).

Kurikulum dikembangkan secara rinci dalam program pertemuan harian yang disebut Rencana Pelaksanaan Pembelajaran (RPP). Menurut penuturan I Nyoman Dharmayasa, seorang guru Agama Hindu SMAN 1 Baturiti, Tabanan, silabus yang dikembangkan secara rinci dalam bentuk RPP telah dapat dilaksanakan dengan cukup baik, tetapi materi pelajaran dalam bentuk praktek yang memerlukan pelatihan siswa yaitu (1) Mengidentifikasi bentuk-bentuk yadnya dalam kehidupan nyata di masyarakat, (2) Melaksanakan yadnya dalam kehidupan nyata di masyarakat, (3) membuat sarana upakara yadnya sebagai wujud rasa bhakti kepada Tuhan, (4) Menerapkan hakekat pelaksanaan yadnya. Indikator tersebut di atas jelas tidak dapat terlaksana dengan baik pada saat pelajaran secara reguler berlangsung karena terbatasnya masalah waktu. Untuk mengatasi hal tersebut, guru Agama Hindu mengembangkan indikator tersebut dalam silabus muatan lokal membuat sarana upakara bebantenan, dan dapat dikembangkan dalam extra kurikuler. Sehingga antara pemahaman teori (cognitif) dan ketrampilan (psikomotor) bagi siswa SMAN 1 Baturiti menjadi seimbang.

\subsubsection{Pengembangan dalam Silabus}

Pengembangan Silabus dilakukan secara sistematis, dan mencakup komponenkomponen yang saling berkaitan untuk 
mencapai kompetensi dasar yang telah ditetapkan. Dalam Kurikulum, Silabus merupakan penjabaran kompetensi inti dan indikator ke dalam materi pembelajaran, kegiatan pembelajaran, dan indikator pencapaian kompetensi untuk penilaian hasil belajar (Mulyasa, 2004: 190). Badan Standar Nasional Pendidikan (BSNP) menyebutkan Silabus adalah rencana pembelajaran pada suatu dan/atau kelompok mata pelajaran/tema tertentu yang mencakup standar kompetensi, kompetensi dasar, mater pokok/pembelajaran, kegiatan pembelajaran, indikator pencapaian kompetensi untuk penilaian, alokasi waktu, dan sumber belajar (BSNP, 2006: 14).

Dengan demikian, pada Kurikulum Tingkat Satuan Pendidikan Silabus disusun oleh guru secara mandiri. Apabila guru mata pelajaran belum mampu mengembangkan silabus secara mandiri, maka pihak sekolah dapat mengusahakan membentuk kelompok guru mata pelajaran untuk mengembangkan Silabus (BSNP, 2006: 15). Implementasinya, Silabus dijabarkan dalam Rencana Pelaksanaan Pembelajaran (RPP), dilaksanakan, dievaluasi, dan ditindaklanjuti oleh masing-masing guru. Dalam rangka pemantapan lebih lanjut, Silabus hendaknya dikaji serta dikembangkan secara berkelanjutan dan terus-menerus dengan memperhatikan hasil evaluasi rencana pembelajaran. Langkah pengembangan silabus memuat sembilan komponen, yaitu: 1) identifikasi, 2) standar kompetensi, 3) kompetensi dasar, 4) materi pokok, 5) pengalaman belajar, 6) indikator, 7) penilaian, 8) alokasi waktu, 9) sumber / bahan / alat (Mansyur, 2007: 39).

Jika dianalisis silabus di depan dari segi durasi waktu yang diperlukan, memerlukan waktu 110 jam (seratus sepuluh jam). Per jam pelajaran durasi waktunya 45 menit. Tiap pertemuan dilaksanakan 2 jam pelajaran. Sehingga pelaksanaan extra kurikuler mejejaitan memerlukan waktu 55 kali pertemuan. Setiap lima kali pertemuan diadakan test atau evaluasi dalam bentuk praktek. Sehingga dengan demikian memerlukan tambahan pertemuan 55: $5=11$.
Jadi dengan demikian bila dianalisis silabus muatan lokal tersebut di atas memerlukan waktu pertemuan $55+11=66$ kali pertemuan. Setiap semester rata-rata program extra kurikuler dapat terlaksana 22 (dua puluh dua kali pertemuan). Oleh karena itu, program extra kurikuler dalam silabus tersebut di depan dapat dilaksanakan dalam kurun waktu tiga semester, yaitu mulai kelas XI semester genap dan kelas XII semester ganjil dan semester genap. Untuk program siswa laki-laki, program membuat gayah belum dapat berjalan dengan baik, karena memerlukan waktu yang cukup banyak, dan ketrampilan khusus bagi siswa dan bagi guru sebagai pembinanya. Menurut penuturan I Wayan Kantun Arimbawa, S.Ag, bahwa program mejejaitan yang telah diprogramkan dalam silabus telah bisa berjalan dengan baik, tetapi program untuk siswa pria, khususnya tentang membuat katik gayah masih banyak menghadapi kendala, kekurangan dan kendala tersebut akan diperbaiki dalam tahun ajaran berikutnya. Rencana Pelaksanaan Pembelajaran (RPP) adalah rencana yang menggambarkan prosedur dan pengorganisasian pembelajaran untuk mencapai satu kompetensi dasar yang ditetapkam dalam standar isi yang dijabarkan dalam silabus. Lingkup rencana pelaksanaan pembelajaran paling luas mencakup satu kompetensi dasar yang terdiri atas satu indikator atau beberapa indikator untuk satu kali pertemuan atau lebih (Sudirga, 2007: 3). Pada hakekatnya Rencana Pelaksanaan Pembelajaran (RPP) merupakan suatu sistem, yang terdiri atas komponen-komponen yang saling berhubungan serta berinteraksi satu sama lain. Komponen-komponen Rencana Pelaksanaan Pembelajaran (RPP), yaitu: identias mata pelajaran, standar kompetensi, kompetensi dasar, indikator, alokasi waktu, tujuan pembelajaran, materi pembelajaran, pendekatan metode pembelajaran, langkahlangkah kegiatan pembelajaran, alat dan penilaian, sumber belajar (Mansur Muslich, 2007: 53).

Dalam pengembangan Rencana Pelaksanaan Pembelajaran (RPP), guru diberi kebebasan untuk mengubah, memodifikasi 
dan menyesuaikan silabus dengan kondisi sekolah dan daerah karakteristik peserta didik (Mulyasa, 2004: 212). Terkait dengan pengembangan Rencana Pelaksanaan Pembelajaran di SMAN 1 Baturiti Tabanan tampaknya tidak dilakukan secara mandiri melainkan secara bersama-sama atau berkelompok, seperti yang dilakukan oleh ketiga guru Agama Hindu.

\subsection{Kendala - kendala yang dihadapi dalam Pengembangan Materi Muatan Lokal di Sekolah Menengah Atas 1 Baturiti \\ 2.2.1 Sumber Daya Manusia (SDM)}

Sumber daya manusia yang dimaksud dalam konteks ini menyangkut tiga faktor sesuai dengan ruang lingkup pendidikan tersebut. Tiga faktor yang dimaksud antara lain: Faktor siswa, guru dan lingkungan. Adapun penjelasannya sebagai berikut: 1) Siswa adalah manusia yang belum dewasa, oleh karena itu disebut anak didik. Maka dari itu ia perlu di didik agar anak menjadi dewasa. Agar siswa menjadi dewasa, siswa itu perlu di didik, yang mendidik siswa secara resmi dan professional adalah guru. Menurut Langend, seorang ahli pendidikan menyatakan manusia pada hakikatnya adalah: a) animal educabila, yaitu mahkluk yang dapat di didik, b) manusia pada hakikatnya Animal Educandum, yaitu makhluk yang harus di didik, c) manusia pada hakikatnya Homo Education : yaitu makhluk yang disamping dapat dan harus di didik juga dapat dan harus mendidik (Suwarno, 1998: 48). Terkait dengan pernyataan diatas siswa sebagai sumber daya manusia yang harus di didik memegang peranan yang paling penting dan paling menentukan keberhasilan suatu proses pendidikan. Bila siswa memiliki potensi,

bakat, berasal dari keluarga yang peduli terh adap pendidikan, dan lingkungan memberikan dukungan, maka secara teori pendidikan itu akan berhasil. Menurut $\mathrm{Ki}$ Hajar Dewantara ke tiga komponen diatas disebut bibit, bebet, bobot.
Berkaitan dengan sumber daya manusia dari faktor siswa, pendidikan keterampilan muatan lokal mejejaitan masih mengalami kendala. Kendala-kendala dari faktor siswa itu muncul disebabkan oleh beberapa faktor. 2) Guru adalah ia yang melaksanakan tugas mendidik anak bangsa agar menjadi dewasa. Dewasa dalam arti seutuhnya dewasa secara phisik, dewasa secara mental moral spiritual dan dewasa secara sosial. Dengan demikian tugas guru sungguh berat adanya. Dalam ilmu wirama guru artinya suara berat, suara panjang (dirga) suara ngileg sehingga menjadi indah dan menarik. Hal tersebut mengandung arti tugas guru sangatlah berat. Bhagawan Sri Salya Saibaba menyatakan bahwa guru artinya ia yang dapat mengahapus segala kebodohan atau kegelapan siswa (awidia) dan dapat menghapus kegelapan dunia. 3) Faktor lingkungan yang dimaksud dalam konteks ini adalah faktor pengaruh orang tua dan lingkungan masyarakat. Orang tua dan lingkungan masyarakat memberi pengaruh besar terhadap perkembangan siswa. Sebagi contoh: bila siswa hidup dilingkungan penjudi, siswa tersebut juga terpengaruh oleh perjudian. Bila siswa hidup di lingkungan pedagang atau pengrajin, siswapun terpengaruh oleh lingkungan pedagang dan pengrajin tersebut. Itu adalah contoh kecil pengaruh lingkungan terhadap perkembangan siswa. Sebagaimana pendapat para ahli tentang besarnya pengaruh lingkungan terhadap pendidikan dengan teori konvergensinya, bahwa berhasilnya suatu pedidikan ditentukan dengan perpaduan antara bakat siswa dan dipadukan dengan sentuhan lingkungannya. Sentuhan lingkungan dimaksudkan adalah sentuhan guru, orang tua dan lingkungan sekitar. Terkait dengan masalah tersebut diatas, peneliti berpendapat dari segi faktor lingkungan juga menghadapi kendala. Orang tua kurang memberi dorongan, kurang mengarahkan putra-putrinya untuk memperlajari ketrampilan majejaitan. Orang tua lebih cenderung berpendapat bahwa keterampilan membuat banten adalah tugas orang tua, bukanlah tugas anak. Hal senada 
dikemukakan oleh orang tua $\mathrm{Ni}$ Kadek Ernawati, ia lebih banyak mengarahkan anaknya untuk mengikuti extra Bahasa Inggris, olah raga, komputer. Sedangkan ketrampilan majejaitan, setelah si anak membangun rumah tangga (kawin) secara otomatis ia akan belajar majejaitan, karena dituntut ngayah di masyarakat.

\subsubsection{Sarana dan Prasarana}

Saran upakara adalah alat yang digunakan secara langsung dalam membuat upakara, sedangkan prasarana adalah tempat alat yang menunjang untuk membuat upakara. Hal yang sama juga dinyatakan oleh guru agama Hindu yang mengajar ketrampilan majejaitan. Prasarana adalah fasilitas yang secara tidak langsung menunjang jalannya proses pendidikan atau pengajaran seperti halaman gedung, kebun, taman sekolah dan jalan menuju sekolah. Jadi dengan demikian sarana yang digunakan dalam extra kurikuler majejaitan antara lain, daun kelapa muda (busung), daun kelapa yang telah tua (selepahan), berbagai jenis bunga, plawa, porosan, semat, ibung, pisau, bambu dan lain sebagainya. Sarana-sarana tersebut pada dasarnya tidaklah begitu sulit didapat, apalagi di Bali pohon kelapa, bunga dan semat sangat cocok di tanam di pulau Bali. Bahkan busung di Bali termasuk berkualitas bagus, bahkan dapat mengalahkan kualitas busung yang di import dari pulau jawa, tetapi dengan jalan membeli. Sarana di dapat dengan jalan membeli adalah cara yang instant. Cara yang lebih mendidik adalah sarana diperoleh dengan cara berusaha mencari sendiri, misalnya untuk mendapat busung mencoba mencari sendiri dari pohon kelapa, agar siswa mengenal lingkungan secara lebih dekat. Untuk mendapatkan semat agar siswa membuat sendiri, bagaimana cara membuat sebuah semat. Kalau hal tersebut diterapkan pada siswa, jelas merupakan suatu kendala, sebab siswa lebih cenderung membeli semat atau paling tidak orang tuanya yang ikut andil dalam membuat semat. Berdasarkan uraian tersebut diatas, pada hakikatnya, masalah pengadaan sarana upakara tidaklah menjadi kendala yang berarti, tetapi justru yang lebih menjadi kendala adalah proses pengerjaan bahan tersebut, misalnya dari membuat semat, membuat bahan sanggah, siswa lebih cenderung membawa bahan yang telah siap pakai.

\subsubsection{Pembiayaan}

Biaya adalah salah satu faktor yang menentukan terselenggaranya pendidikan dengan baik dan dapat berkesinambungan. Pendidikan yang maju dan memerlukan fasilitas yang memadai memerlukan biaya yang cukup tinggi. Pendidikan zaman sekarang memerlukan sarana prasana yang cukup banyak dan cukup mahal. Misalnya buku paket dan buku penunjang, peralatan yang dikenal dengan istilah ATK, Computer laptop, internet, lab, alat peraga dan peralatan yang lainnya. Bila dikalkulasi biaya praktek majejaitan tidaklah memerlukan biaya tinggi, tetapi yang memerlukan biayanya tinggi adalah biaya pembelian buku, ATK, praktek computer, laptop, plasdist, internet. Oleh karena biaya pendidikan yang bersifat regular di atas cukup tinggi, maka kebiasaan siswa biasanya mengutamakan biaya tersebut diatas terlebih dahulu. Karena sarana tersebut diatas sangat erat kaitannya dengan mata diklat yang akan diujikan. Sehingga terjadilah suatu mata pelajaran yang lebih diutamakan dan pelajaran yang tidak diutamakan, bahkan ada pelajaran yang dianggap tidak penting, sehingga di anak tirikan oleh siswa.

Berbagai alasan yang disampaikan oleh siswa, mengapa mereka lebih mengutamakan untuk membiayai extra atau ketrampilan lain selain majejaitan, seperti komputer, menari, olah raga. Seorang siswi yang bernama Ni Putu Oka Ariantini menyatakan bahwa mereka kurang tertarik mempelajari ketrampilan mejejaitan karena telah banyak mengeluarkan biaya untuk keperluan ketrampilan yang lain, disamping itu juga ketrampilan majejaitan tidak menentukan kelulusan. Dari penelusuran peneliti dan hasil wawancara peneliti dengan para siswa, maka peneliti menyimpulkan bahwa masalah pembiayaan masih masih menjadi kendala dalam rangka 
pengembangan ketrampilan muatan lokal majejaitan di SMA N 1 Baturiti. Meskipun program tersebut masih tetap jalan, dan siswa banyak pula yang tertarik belajar ketrampilan bebantenan. Pihak guru dan sekolah tetap memberi dorongan, arahan dan pandangan akan pentingnya belajar bebantenan sebagai aset budaya Bali yang bersifat magis religius dan adiluhung.

\subsubsection{Lingkungan Sekolah}

Lingkungan sosial SMA N 1 Baturiti Tabanan tak terlepas dari pengaruh lingkungan sosial dan ekonomis daerah Kecamatan Baturiti. Daerah Baturiti adalah daerah pertanian khususnya daerah perkebunan yang berhawa sejuk dan penghasilan sayur-sayuran terbaik di Bali. Hasil perkebunan seperti kul, tomat, kentang, sawi, wortel, bayam, stroberi adalah berasal dari daerah Baturiti. Di Baturiti terdapat pasar yang menjual berbagai jenis sayuran dan buah-buahan terbesar di Tabanan. Pasar sayuran tersebut bergabung dengan pasar wisata di Kecamatan Baturiti. Karena daerah baturiti menyajikan alam yang cukup mempesona dengan hawanya yang dingin, dan ditambah dengan tempat wisata Bedugul dengan taman Eka Karya. Ditambah pula dengan wisata tirta danau Baratannya.

Kondisi alam dan lingkungan sosial yang demikian memberi pengaruh terhadap minat siswa dalam memilih suatu ketrampilan. Siswa lebih cenderung membantu bisnis orang tuanya dalam menjual hasil pertanian dan peternakannya utamanya hasil kebun dan peternakan sapinya, yang berkembang cukup baik di Baturiti. Jadi dengan demikian siswa lebih memilih membantu usaha bisnis orang tuanya dalam mengelola dan menjual hasil kebunnya. Adapun siswa yang tertarik mempelajari ketrampilan bebantenan setelah peneliti mewawancarai beberapa siswa disebabkan oleh beberapa alasan yang cukup logis. Jadi ketrampilan membuat banten disamping sebagai wujud pelaksanaan ajaran bhakti marga dan karma marga, juga digunakan sebagai ajang bisnis atau sebagai mata pencaharian sehari-hari
Hasil penelitian menyatakan bahwa siswa tertarik mempelajari upakara bebantenan, oleh karena orang tuanya selalu sibuk mengurus bisnis jualan sayur sehingga sering diberi tugas membuat banten, sekaligus sering diberi tugas mebanten, bahkan sering kali ditugaskan ngayah di banjar atau di pura oleh orang tuanya untuk mewakili orang tuanya yang mempunyai banyak kesibukan.

Kesimpulannya bahwa faktor lingkungan memberi pengaruh besar terhadap minat siswa dalam mempelajari suatu ketrampilan. Ada siswa yang masih mengalami kendala dalam memilih mempelajari ketrampilan upakara karena faktor pengaruh lingkungan. Tetapi disisi lain ada pula siswa yang tertarik mempelajari ketrampilan bebantenan, oleh karena faktor lingkungan pula. Dalam ilmu pendidikan belajar dengan memadukan antara bakat atau pembawaan dengan pengaruh lingkungan disebut teori konvergensi. Teori tersebut hendaknya dipakai acuan dalam meningkatkan sumber daya anak didik, siswa-siswa dapat berkembang sesuai dengan bakatnya dan ditunjang oleh lingkungan yang bersifat positif.

\subsection{Upaya Pengembangan Materi Muatan Lokal di Sekolah Menengah Atas 1 Baturiti 2.3.1 Upaya Guru}

Muatan lokal telah diupayakan dikembangkan di SMA N 1 Baturiti Tabanan. Muatan lokal yang dikembangkan di SMA N 1 Baturiti adalah ketrampilan upakara yang terdiri dari majejaitan bagi siswa perempuan dan anyaman upakara bagi siswa laki-laki. Muatan lokal tentang ketrampilan membuat upakara itu dipilih, oleh karena upakara adalah salah satu sarana melaksanakan yadnya. Melaksanakan yadnya adalah salah satu kewajiban umat Hindu. Jadi ketrampilan membuat upakara adalah penunjang yang paling utama terhadap pelaksanaan agama Hindu di Bali. Disamping itu bila dikaitkan dengan ajaran Catur Marga, membuat upakara dan mempersembahkannya dalam bentuk yadnya adalah perpaduan pelaksanaan ajaran Bhakti Marga dan ajaran Karma 
Marga. Berdasarkan alasan yang strategis itulah SMA N 1 Baturiti memilih ketrampilan membuat upakara banten sebagai pilihan utama dalam pengembangan muatan lokal.

Setiap purnama dan tilem guru dan siswa SMA N 1 Baturiti mengadakan sembahyang bersama ditempat suci sekolah SMK N 1 Baturiti Tabanan. Dalam persembahyangan bersama itu upakara berupa pejati, yang terdiri dari wangi daksina peras lis diupayakan disiapkan oleh pihak sekolah, jadi tidak dengan membeli di pasar. Upaya tersebut dilaksanakan oleh para guru, agar siswa dapat berperan aktif dan terbiasa membuat sarana upakara. Untuk membuat sarana upakara berupa pejati tersebut akhirnya melibatkan para siswa, utamanya siswa perempuan, dengan membuat pejati bersama-sama dibimbing oleh para guru, utamanya guru agama Hindu. Adapun tehnik pengaturannya diatur sedemikian rupa secara bergiliran masing-masing kelas bertanggung jawab membuat tiga buah pejati setiap purnama dan tilem. Banten pejati tersebut dihaturkan pada pelinggih Padmasana, Tugu dan sebuah pelinggih Taksu. Upaya tersebut ternyata mampu mendorong para siswa untuk berperan aktif untuk terus berpartisipasi dalam rangka membuat banten pejati dan sarana sembahyang lainnya.

Untuk memupuk kepedulian siswa terhadap setiap upacara keagamaan yang dilakukan di rumah tangga dan di masyarakat, guru agama kerap kali memberi tugas terhadap siswa agar mengamati pelaksanaan upacara keagamaan di rumahnya sendiri, misalnya: upacara ngotonin, upacara ngodalin di tempat suci keluarga, upacara melukat. Siswa kemudian membuat laporan tertulis, yang isinya: (1) nama upacara kegamaan, (2) kapan dan dimana dilaksanakan, (3) apa saja jenis bebantenannya, (4) bagaimana kronologis jalannya upacara tersebut. Dengan laporan yang sistematis tersebut, siswa dipicu untuk mengadakan pengamatan secara langsung dan mendalam. Pada upacara agama yang sederhana siswa dituntut untuk mempresentasikan hasil pengamatannya didalam kelas. Melalui upaya tersebut di atas para siswa akhirnya berusaha melaksanakan tugas yang dibebankan oleh guru, agar mereka mampu mempresentasikan di depan yang ditonton dan didengar oleh teman-teman sekelasnya.

\subsubsection{Upaya Sekolah}

Upaya sekolah dalam mengembangkan ketrampilan membuat upakara merupakan lanjutan dari upaya guru yang telah dirintis. Sebelumnya dengan memberikan beberapa kegiatan yang membuat siswa menjadi aktif dalam kegiatan membuat sarana upakara bebantenan. Upaya guru tersebut di depan, kemudian dilanjutkan dengan upaya sekolah dalam mempermanenkan upaya guru tersebut. Langkah-langkah sekolah diambil untuk melanjutkan upaya guru tersebut dengan cara atau jalan membuat pedoman atau dengan terlebih dahulu menyusun silabus muatan lokal majejaitan. Menyusun silabus muatan lokal majejaitan sepenuhnya. Diserahkan pada guru agama sebagai tim penyusunnya, pihak sekolah hanya menyediakan fasilitas dan menunjang pembiayaannya saja.

Atas kerja keras guru agama di SMA N 1 Baturiti mewakili sekolah, maka lahirlah sebuah pedoman dalam mengembangkan materi muatan lokal majejaitan. Buku pedoman tersebut disebut silabus muatan lokal majejaitan. Adapun materinya disajikan sebagaimana uraian berikut ini. Upaya guru untuk mencapai keberhasilan dalam pengembangan muatan lokal mejejaitan diupayakan pula dengan mengadakan pendekatan pada orang tua siswa, agar orang tua siswa ikut mendidik putra putrinya dalam membuat sarana upakara bebantenan dengan cara memberi tugas pada putra - putrinya untuk membuat sarana-sarana bebantenan, sehingga siswa juga aktif di rumah belajar mejejaitan. Sehingga upaya guru mengajar mejejaitan menjadi berkesinambungan di rumah, yang dapat dibimbing oleh orang tuanya.

\subsubsection{Upaya Komite}

Komite sekolah adalah suatu organisasi yang dibentuk oleh pihak sekolah 
dalam rangka kerjasama membantu sekolah dalam pelaksanaan program pemerintah dalam bidang pendidikan dan program sekolah yang merupakan program otonomi yang dimiliki oleh sekolah. Anggota dari komite sekolah itu sifatnya fleksibel. Bisa dari tokoh masyarakat, tokoh pendidikan, orang tua siswa atau juga dari unsur guru, atau tokoh masyarakat yang punya kepedulian terhadap pendidikan. Tugas komite sekolah adalah membantu sekolah dalam rangka memperlancar dan mensukseskan proses belajar mengajar di sekolah tertentu. Komite sekolah biasanya sebagai mediator antara guru yang menyelenggarakan pendidikan kepada orang tua wali siswa yang anaknya sedang mengikuti proses belajar mengajar di suatu sekolah, termasuk di SMA N 1 Baturiti.

Setelah program kerja disusun bersama-sama pengurus komite sekolah, maka program itu diajukan pada orang tua siswa melalui rapat komite sekolah. Program itu disusun dan diajukan secara komprehensip dari program pembangunan phisik, program pendidikan secara regular, program ekstrakurikuler dan program lainnya sesuai dengan perkembangan pendidikan dewasa ini. Dalam rapat komite biasanya terjadi perdebatan antara orang tua siswa dan guru sebagai penyelenggara pendidikan untuk mencari titik temu agar program dapat dilaksanakan. Jadi dengan demikian, komite sekolah pada hakikatnya sangat berperan dalam melaksanakan pendidikan termasuk di dalamnya adalah program ekstrakurikuler majejaitan. Komite SMA N 1 Baturiti Tabanan bukan hanya berperan dalam menentukan beban keuangan yang wajib ditanggung oleh orang tua siswa, tetapi juga ikut menentukan program-program pendidikan yang bersifat regular dan program ekstrakurikuler yang bersifat otonom.

\subsubsection{Upaya Masyarakat}

Menurut teori pendidikan terutama yang dikemukakan oleh Ki Hajar Dewantara dinyatakan ada tiga pusat pendidikan, yang disebut Tri Pusat Pendidikan yaitu : Pendidikan keluarga, pendidikan oleh pemerintah atau sekolah dan masyarakat
(Hasbullah, 2018: 37). Lebih lanjut Hasbullah (2018: 37) menyatakan tiga pusat pendidikan yang secara bertahap dan terpadu mengemban suatu tanggung jawab pendidikan bagi generasi mudanya. Ketiga penanggung jawab pendidikan ini dituntut melakukan kerjasama diantara mereka baik secara langsung maupun tidak langsung, dengan saling menopang kegiatan sama secara sendiri-sendiri, maupun bersama-sama. Dengan kata lain, perbuatan mendidik yang dilakukan oleh orang tua terhadap anak, juga dilakukan oleh sekolah dengan memperkuatnya serta dikontrol oleh masyarakat sebagai lingkungan sosial anak.

Merenungkan pendapat Hasbullah sebagai seorang ahli pendidikan, cukup jelas bahwa pendidikan itu bukan hanya tanggung jawab pihak sekolah, tetapi juga tanggung jawab orang tua dan masyarakat. Dari segi durasi waktu, anak didik hanya ada 6 jam di sekolah dari 24 jam waktu tersedia, sisanya 18 jam lagi siswa ada dalam keluarga dan masyarakat. Maka dari itu berhasil dan tidak berhasilnya suatu pendidikan ditentukan oleh tiga komponen, yaitu keluarga, pemerintah dan masyarakat. Lebih lanjut dalam GBHN 1978 dinyatakan bahwa pendidikan berlangsung seumur hidup dan dilaksanakan di dalam lingkungan rumah tangga, sekolah dan masyarakat. Karena itu pendidikan merupakan tanggung jawab bersama antara keluarga, masyarakat dan pemerintah (Hasbullah, 2018: 63). Dalam GBHN 1993 dinyatakan pula, bahwa pendidikan nasional dikembangkan secara terpadu dan serasi, baik antara berbagai jalur jenis dan jenjang pendidikan maupun antara sektor pendidikan dengan sektor pembangunan lainnya serta antar daerah. Masyarakat sebagai mitra pemerintah berkesempatan seluas-luasnya untuk berperan serta dalam penyelenggaraan pendidikan nasional (Hasbullah, 2018: 72).

Memperhatikan beberapa rumusan pendidikan di atas, jelaslah bahwa pendidikan itu adalah tanggung jawab bersama antara orang tua, pemerintah dan masyarakat. Hal itu mengandung arti bahwa disamping pemerintah, peran orang tua dan masyarakat amat penting dan amat besar dalam dunia pendidikan. Peran orang tua dan masyarakat 
terhadap pendidikan itulah tergabung dalam komite sekolah. Antara dunia pendidikan pada hakikatnya saling mempengaruhi (Muslich, 2008: 15). Pendidikan itu akan dipengaruhi oleh corak kehidupan sosial masyarakat, demikian pula sebaliknya apabila di masyarakat banyak orang terpelajar atau orang intelektual, maka hal itu dapat mempengaruhi kehidupan sosial masyarakat. Muhamad Noor Syam mengatakan bahwa hubungan masyarakat dengan pendidikan sangat bersifat kolektif, bahkan seperti telur dengan ayam. Kurikulum dan pengajaran merupakan dua hal yang tidak bisa dipisahkan (Sanjaya, 2008: 12).

Terkait dengan peran masyarakat dalam dunia pendidikan, dimana sekolah harus dapat menangkap kepentingan masyarakat, maka masyarakat Bali yang mayoritas beragama Hindu, dimana masyarakat Hindu di Bali tidak dapat dilepaskan dari upacara keagamaan, dan upacara keagamaan tidak dipisahkan dari upakara. Pesan-pesan kehidupan masyarakat itulah dapat ditangkap oleh guruguru SMA N 1 Baturiti, maka tepatlah apabila muatan lokal yang dipilih adalah majejaitan sebagai muatan lokal yang diunggulkan. Dengan kata lain dengan program muatan lokal majejaitan diwajibkan di SMA N 1 Baturiti berarti mengfungsikan secara aktif dan berdaya guna lembaga pendidikan untuk kepentingan masyarakat dan mengaktifkan masyarakat dalam dunia pendidikan.

\section{PENUTUP}

Pengembangan muatan lokal majejaitan atau upakara sangat penting dikembangkan di tingkat SMA terutama SMA di wilayah propinsi Bali, karena menunjang pelaksanaan agama Hindu terutama dalam bidang upacara Yadnya. Pengembangan muatan lokal majejaitan di SMA N 1 Baturiti Tabanan dilaksanakan dalam bentuk extra kurikuler, oleh karena waktu dalam pelajaran reguler tidak memungkinkan. SMA N 1 Baturiti telah mempunyai pedoman yang difinitif tentang program muatan lokal majejaitan berupa silabus muatan lokal majejaitan yang disusun oleh guru-guru SMA
N 1 Baturiti Tabanan. Program pengembangan lokal majejaitan di SMA N 1 Baturiti masih mengalami banyak kendala. Kendala tersebut disebabkan oleh sumber daya manusia, sarana dan dari pembiayaan. Kendala dari faktor sumber daya manusia disebabkan oleh siswa yang kurang siap, kurang ada dorongan dari orang tua siswa, dan siswa masih beranggapan bahwa membuat upakara adalah tugas orang tua. Kendala dari faktor guru disebabkan oleh tidak semua guru agama mempunyai keahlian dalam membuat upakara, dan tidak semua guru agama ahli dalam membahas makna filosofis dari bebantenan. Kendala dari faktor pembiayaan, karena tidak semua siswa memiliki kemampuan, masih banyak siswa yang tergolong siswa yang tidak mampu. Program muatan lokal majejaitan di SMA N 1 Baturiti Tabanan telah diupayakan secara bersinergi antara upaya guru memberi dorongan dan pengertian pada siswa, upaya sekolah menyiapkan silabus dan menyusun program secara difinitif. Upaya komite membantu dari segi keuangan dan membangun semangat sekolah, dan upaya masyarakat dalam memberi dorongan moril. Belum semua program yang tercantun dalam silabus dapat dilaksanakan dalam extra kurikuler majejaitan. Berikutnya semua program itu dapat diupayakan dilaksanakan dengan baik.

\section{DAFTAR PUSTAKA}

BSNP. (2006). Permendiknas Nomor 22 Tahun 2006. Jakarta: Departemen Pendidikan Nasional.

Dantes, I. N. (1966). Orientasi Tentang Profesi Guru dan Pengembangannya. STKIP Singaraja.

Hasbullah. (2018). Dasar-Dasar Ilmu Pendidikan. Rajawali Pers.

Mansyur, M. (2007). Kurikulum Tingkat Dasar Pendidikan, Dasar Pengembangan dan Pemahamannya. Bumi Aksara.

Mulyasa, E. (2014). Manajemen Paud. In Manajemen PAUD.

Muslich, M. (2008). KTSP Pembelajaran Berbasis Kompetensi Dan 
Kontekstual. Jakarta: PT. Bumi Aksara. https://doi.org/10.1016/j.sbspro.2014. 09.352

Sanjaya, W. (2008). Kurikulum dan pembelajaran: teori dan praktik pengembangan kurikulum tingkat satuan pendidikan (KTSP). Jakarta: Kencana.

Sudirga, I. (2007). Widya Dharma Agama Hindu untuk SMA. Ganeca Exact.

Susilo, M. J. (2015). Analisis Kualitas Media Pembelajaran Insektarium dan Herbarium untuk Mata Pelajaran Biologi Sekolah Menengah. JURNAL BIOEDUKATIKA.

https://doi.org/10.26555/bioedukatika .v3i1.4141
Sutriyanti, N. K. (2017). IMPLEMENTASI KURIKULUM $2013 \quad$ PADA PEMBELAJARAN PENDIDIKAN AGAMA HINDU TINGKAT SEKOLAH DASAR DI KOTA DENPASAR. Vidya Samhita, 3(1), 97-113.

Sutriyanti, N. K. (2020). Metode Pembelajaran Pasraman Hindu (Dalam Membentuk Karakter Anak Didik). Yayasan Gandhi Puri.

Suwarno. (1998). Pengantar Umum Pendidikan. Aksara Baru.

Tillar, H. A. . (1992). Pembangunan Pendidikan Nasional. Remaja Rosdakarya. 